\title{
Traditional Fermentation and Distillation of Raffia Palm Sap for the Production of Bioethanol in Bayelsa State, Nigeria
}

\author{
Elijah I. Ohimain*, Patrick E. Tuwon and Ekiemene A. Ayibaebi
}

\author{
Bioenergy and Environmental Biotechnology Research Unit, Biological Sciences Department, Faculty of \\ Science, Niger Delta University, Wilberforce Island, Amassoma, Bayelsa State, Nigeria
}

\begin{abstract}
The production of alcoholic beverages from the sap of raffia palm, Raphia hookeri, has continued for decades in West Africa, but the detailed processes had never been documented before. The objective of this study is to document the traditional process of ethanol production, with the aim of scaling up the process for the production of fuel ethanol. Ten smallholder ethanol production facilities were randomly selected, and triplicate samples of the process intermediates were collected and analysed, including fermented palm sap, first and second distillate, first and second stillage. Results show that the percentage of ethanol was significantly different $(\mathrm{P}<0.05)$ among the different intermediates. The highest ethanol presence was recorded in the second distillate (39-61.5\%), followed by the first distillate (18.83-39\%), then the first stillage (5.80-10.20\%), the palm sap (10.50-15.30\%) and finally the second stillage (3.40-5.80\%). Yeast population, $\mathrm{pH}$, sugar, specific gravity and electrical conductivity differed significantly among the various sites and intermediates. Wood $(105-155 \mathrm{~kg}$ ) was used as fuel to boil $280-480 \mathrm{~L}$ of fermented palm sap producing $20 \mathrm{~L}$ of $39-61.5 \%$ ethanol. The smallholder processors are however challenged by the poor distillation apparatus and the lack of ethanol dehydration facilities. The study concludes by recommending the modification of the Nigerian Biofuel Policy (2007) to allow the use of hydrous ethanol in automobiles and low concentration ethanol for household cooking
\end{abstract}

Keywords: Biofuel conversion, distillate, fuel ethanol, innovation, stillage, sugar.

\section{INTRODUCTION}

The production of ethanol from agricultural feedstock for use as alternative fuel has attracted worldwide attention because of the depleting fossil fuel sources and volatile petroleum prices in the international market [1]. Many countries are seeking alternative sources of energy that can be produced locally [2]. Palm wine is an alcoholic beverage that is widely consumed in the tropical world, especially in West Africa. Palm wine is produced via natural fermentation of the sap of raffia palm, Raphia hookeri and oil palm, Elaeis guineensis [3-5]. Nwachukwu et al. [6] reported that palm wine is consumed by over 10 million people in Africa. The saps of raffia and oil palm have been widely reported to contain sugars - mostly glucose and sucrose - which are excellent substrates for yeast and bacteria fermentation. Obahiagbon [7] indicates that the sweet taste of raffia palm sap is due to the presence of sucrose. Obahiagbon and Osagie [8] report a maximum of $9.5 \%$ sucrose content of raffia palm sap. The study also reveals that raffia palm sap contains several other sugars such as glucose, fructose and raffinose, but concludes that sucrose contributed over $95 \%$ of the sugar in raffia palm sap. Similarly, Eze and Ogan [9] report that the sap of oil palm contain sucrose as the dominant sugar,

\footnotetext{
*Address corresponding to this author at Bioenergy and Environmental Biotechnology Research Unit, Biological Sciences Department, Faculty of Science, Niger Delta University, Wilberforce Island, Amassoma, Bayelsa State, Nigeria; Tel: 234-8037306520; Fax: 234-8033362761;

E-mail: eohimain@yahoo.com
}

accounting for $10 \% \mathrm{w} / \mathrm{v}$, whereas glucose and fructose account for $<1.0 \% \mathrm{w} / \mathrm{v}$. However, a study in Malaysia shows that glucose is the dominant sugar in oil palm sap [10]. Several other studies show that the unfermented palm sap contains about $10-20 \%$ sugar dominated by sucrose, whereas upon fermentation sucrose is first broken down to glucose and fructose, which are then converted to ethanol, lactic acid and other products via fermentation $[3,8,10,11]$.

Studies have shown that the microbial infestation of palm sap, which promotes the proliferation of yeast and bacteria for the conversion of the sugary sap into ethanol, is a spontaneous process $[12,13]$. Several other studies have shown that the alcohol fermenting yeast Saccharomyces cerevisiae naturally colonizes palm wine sap [6, 14-18]. Ezeronye and Okerentugba [16] report that palm wine yeast produces alcohol in the range of $5.8-8.8 \%$. Alcohol tolerance of fermenting yeast has been generally reported to be in the order of $12 \%$ [19], but Nwachukwu et al. [14] reports some stains of palm wine yeast that tolerated $10-20 \%$ ethanol.

The distillate that is produced from the fermented palm sap is called in various ways in West Africa: 'ogogoro', 'kaikai'or'apeteshi' [5, 20, 21]. The aqueous by-product from the distillation of ethanol from fermented broth is called stillage, spent wash, distillery wastewater, or vinasse $[1,2,22]$. Stillage production and handling are typically challenging processes in all ethanol production facilities in the world. It has been 
reported that a typical distillery produces about 13 litres of stillage per litre of ethanol produced $[2,23]$. Other authors report 15 litres of stillage is generated per litre of ethanol [1,24]. A few authors report 20 litres of stillage per litre of ethanol produced [22, 25]. It therefore follows that stillage may account for $80-87 \%$ of the fermented broth. This presents a huge volume of wastewater. Stillage is known to be an environmental hazard because of its high content of BOD $(35-50 \mathrm{~g} / \mathrm{l})$, COD (100-150g/l) among other parameters [26].

The alcohol content of fermented sap is dependent on the ethanol productivity and tolerance of the fermenting yeast, and on the efficiency of the distillation. However in most cases, middlemen dilute the ethanol beverage before selling it to customers. Notwithstanding this, ogogoro have been variously reported to have alcohol content of $37.6 \%$ [21], > 40\% [20], 30-60\% [27, 28]. This high concentration of ethanol produced via rudimentary equipment [29] suggests the possibility of scaling up the traditional beverage ethanol produced from raffia palm as a possible source of fuel ethanol. Besides, raffia palm has been described as hapazanthic i.e. after a period of vegetative growth, it produces flower and fruits only once and dies [7,8], thus resulting in the loss of important biomass/energy feedstock. Feedstock for ethanol production varies among countries. The US, the leading ethanol producing country in the world, produces ethanol mostly from corn [30], while the second leading ethanol producing country, Brazil produces ethanol mostly from sugarcane [31, 32]. However, the Nigerian biofuel policy recommends sugarcane, sweet sorghum and cassava [33] as feedstock. The use of these food crops for fuel ethanol production could potentially cause a conflict of use between food and fuel. Hence, alternative feedstock is being sought for ethanol production. Cellulosic feedstock is currently being promoted as viable alternative for fuel ethanol production. Ethanol produced from sugarcane, corn and raffia palm have been shown to exhibit good engine performance [34] hence, this study is aimed at scaling up the traditional raffia palm fermentation for fuel ethanol production. The traditional fermentation and production of ethanol has in fact been practiced for decades in West Africa, yet the detailed process has not been documented.

\section{MATERIALS AND METHODS}

\section{Field Sampling}

Ten traditional ethanol processing facilities were randomly selected in Bayelsa State, Nigeria for sample collection. Batch processes for ethanol production were carried out in all the sites. Triplicate samples of fermented raffia palm sap, first and second distillate, first and second stillage were collected for laboratory analysis. The volumes of each intermediate were measured in the field, while the amount of fire wood used for the distillation process was measured using spring dial weighing balance. Conductivity and $\mathrm{pH}$ were determined in situ using Hach's CO 150 conductivity/TDS meter and $\mathrm{pH}$ meter respectively. The number of personnel involved in the distillation of process was counted in each of the sites, while the duration of the distillation process was measured using a stop clock.

\section{Laboratory Analysis}

The specific gravity (SG) of the samples was determined with the use of specific gravity bottles. The specific gravity bottles with the glass stopper were filled to the brim i.e. overflowing with the various fractions of the palm wine products. All spillage on the body of the bottle was cleaned after the bottle had been stopped with the glass stopper. The weight of the bottle was measured with analytical balance (Metler Toledo) and the SG was calculated using the formula

$$
S G=\frac{\text { Mass of SG bottle }+ \text { samples }- \text { Mass of the empty bottle }}{\text { Volume of SG bottle }}
$$

The percentage alcohol content of the various samples was determined with the $\mathrm{K}_{2} \mathrm{Cr}_{2} \mathrm{O}_{7}$ method. An alcohol standard curve was prepared by diluting a $98 \%$ - $100 \%$ absolute ethanol, to give a series of standards, $20 \%-80 \%$. From each of these standard solutions, $1 \mathrm{ml}$ of alcohol was added into a test tube and $5 \mathrm{ml}$ of $0.1 \mathrm{M} \mathrm{K}_{2} \mathrm{Cr}_{2} \mathrm{O}_{7}$ was added and incubated for 30 minutes at room temperature. The spectrophotometer (Jenway 6505 UV/VIS) was set up at a wavelength of $540 \mathrm{~nm}$. The blank used in this case was $1 \mathrm{ml}$ of distilled water in a test tube and $5 \mathrm{ml}$ of $0.1 \mathrm{~m} \mathrm{~K}_{2} \mathrm{Cr}_{2} \mathrm{O}_{7}$ added and incubated at room temperature for 30 minutes. This was used to zero the spectrophotometer, and absorption values were then taken, the curve obtained was linear. The samples were also treated in the same manner and their absorbances were measured. A standard graph of absorbance versus alcohol percentage was drawn, and alcohol percentage values were calculated by extrapolation from the curve [15].

The Percentage of sugar content in the various samples was determined with the use of potassium ferricyanate in the presence of $\mathrm{NaOH}$. $1 \mathrm{ml}$ of the 
filtered sample was put into a test tube followed by the additional of $5 \mathrm{ml}$ of 0.1 , potassium ferricyanate solution and $1 \mathrm{ml}$ of $2 \mathrm{M} \mathrm{NaOH}$ solution. The test tubes were then placed in a water bath at $100^{\circ} \mathrm{C}$ and incubated for 10-15 min until the greenish yellow colour developed. A standard $100 \%$ sugar solution was prepared as the stock sugar solution from D-glucose crystals by weighing $100 \mathrm{~g}$ of glucose into $100 \mathrm{ml}$ volumetric flask and making up to the mark with distilled water. By using the $M_{1} V_{1}=M_{2} V_{2}$ relationship, various dilutions ranging from $20 \%-80 \%$ were created.
Using the same procedure as that of the samples, the standard glucose solution was treated. The spectrophotometer was set at $420 \mathrm{~nm}$ after incubation. Absorbance values were taken and a calibration curve was drawn. The percentage of sugar was determined by extrapolation from the standard curve.

\section{Yeast Counts and Identification}

Serially diluted palm wine sap was plated on sabouraud dextrose agar containing $0.05 \mathrm{mg} / \mathrm{ml}$

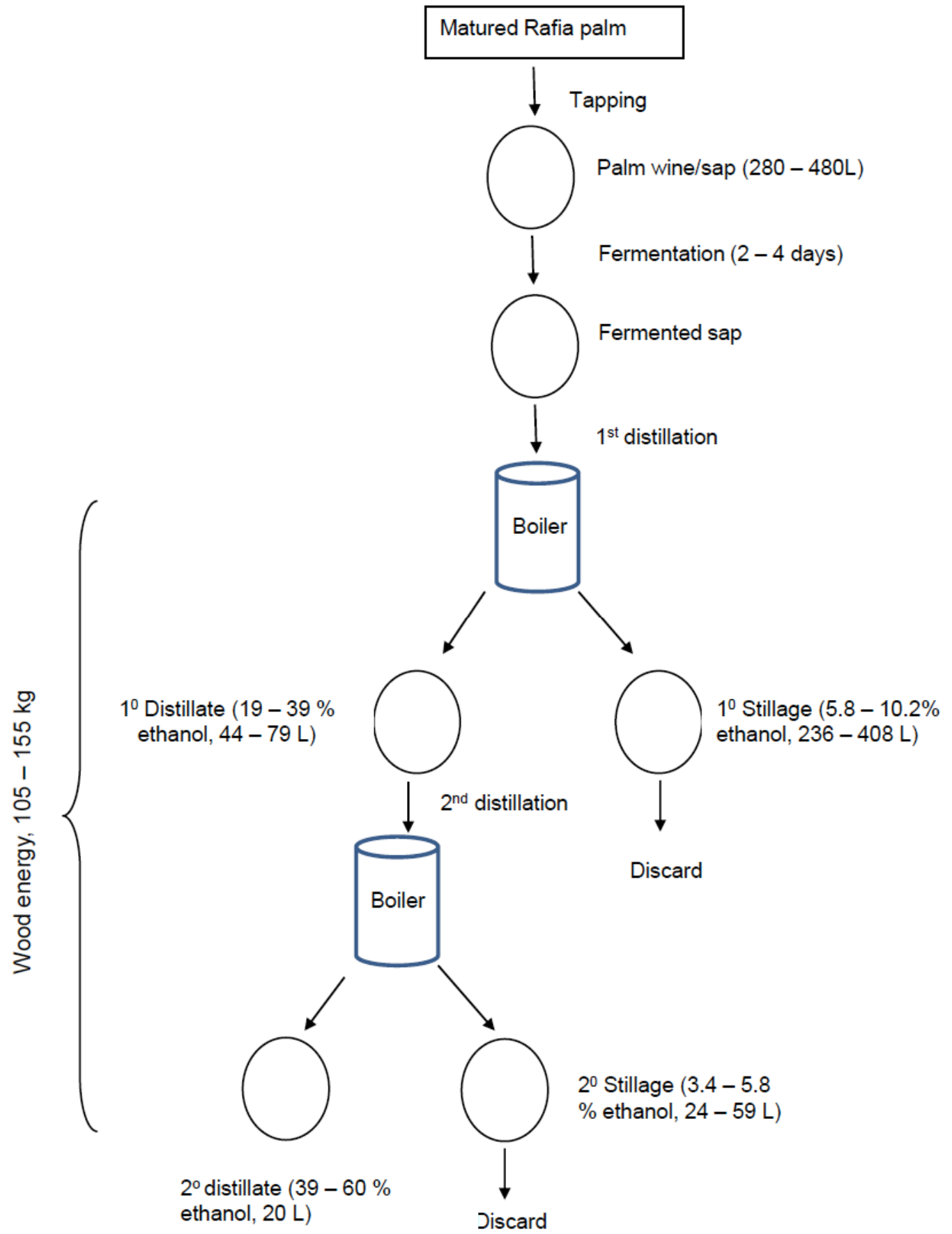

Figure 1: Batch process for the traditional fermentation and distillation of raffia palm sap for ethanol production. 
chloramphenicol for yeast counts. The yeast was identified with morphological, cultural, and biochemical tests [14].

\section{Statistical Analysis}

SPSS software version 17 (SPSS Inc, Chicago) was used to carry out the statistical analysis. A one-way analysis of variance was carried out at $\alpha=0.05$, and Duncan's multiple range test was used to discern the source of the observed differences.

\section{RESULTS AND DISCUSSIONS}

The traditional fermentation and distillation of raffia palm sap for the production of ethanol in Bayelsa State, Nigeria, is carried out in a batch process (Figure 1). In the ten studied sites, 280-480 litres of fermented sap was distilled using makeshift rudimentary equipment (Figure 2), the volume of the fermented sap being significantly different $(P<0.05)$ in the different sites (Table 1). After the first cycle of distillation, a diluted ethanol called primary or first distillate is produced, which is re-distilled to produce concentrated ethanol, often referred to as 'secondary or second distillate' or simply called ethanol. During both distillation processes, primary or first stillage and secondary or second stillage are produced as by-products. The volumes of the primary distillate (44-79L), primary stillage (236-408L) and secondary stillage (24-59L) are significantly different $(\mathrm{P}<0.05)$ among the various sites. The volume of ethanol produced, which is $20 \mathrm{~L}$ per batch, is basically the same among the different sites $(P>0.05)$, which forms the basis for comparison among the sites (for the purpose of normalization of the data), since the $20 \mathrm{~L}$ is a common denominator among the various sites. Therefore, per litre of ethanol, 13-23.35 litres of stillage were produced, not including the recycling cooling water. This volume of stillage produced is within the range reported by various authors [1, 2, 7, 22-25]. The sap of raffia palm is made up of over $90 \%$ water [7]. Hence, using raffia palm sap as feedstock for ethanol production will expectedly yield large volume of stillage. Wilkie et al. [22] reported that ethanol production processes particularly hydrolysis, fermentation and distillation affect the quality and quantity of stillage produced and their possible utilization. For the production of ethanol to qualify as a sustainable 'green energy' process, consideration for treatment and utilization of the stillage by-product is essential [22].

Unlike sugar and starch-based crops, the relative abundance of cellulosic feedstock suggests that large- scale production of cellulosic ethanol has great potential to replace a major portion of imported fuel [22, 35]. However, large-scale ethanol production may have limited benefits [29, 36], hence a large number of small-scale ethanol production facilities is more desirable. Besides, large-scale ethanol refineries will require massive capital investments and long lead times and items [2]. The participation of smallholders is very important to the sustainability of biofuel.

The batch process of ethanol production is carried out by 2-5 workers in a period of time that differs greatly among the various sites, ranging from 5 hours 32 minutes to 12 hours 33 minutes. About $105-155 \mathrm{~kg}$ of hard wood being significantly different $(P<0.05)$ among the various sites, was the source of energy used for the distillation of $20 \mathrm{~L}$ of ethanol, which is done in open furnace (Figure 2). Thus, this indicates that about $5.25-7.75 \mathrm{~kg}$ of wood is consumed to distil one litre of ethanol. Energy and labour related inputs are important issues in energy assessment and sustainability. Knowing that the gross energy content of most Nigerian hard wood is in the range of $18-22 \mathrm{MJ} / \mathrm{kg}$ $[37,38]$, it therefore appears that the traditional distillation process is energy inefficient because the energy content of pure ethanol and low concentration ethanol (39-61.5\%) are $21.2 \mathrm{MJ} / \mathrm{L}$ and $13.9 \mathrm{MJ} / \mathrm{L}$ respectively. Igbinadolor [13] describes the process of traditional production of ethanol to involve pooling palm saps into metal drums where they are thoroughly mixed, and allowed to ferment for 24 hours with occasional stirring. The fermented sap is then distilled over fire; the vapour is condensed as ethanol. The first distillate is re-distilled to obtain a product with higher ethanol content.

Table 2 presents the yeast counts and physicochemical properties of the fermented sap prior to distillation. The yeast population is in the order of $0.75-185 \times 10^{8} \mathrm{cfu} / \mathrm{ml}$ being significantly different in the various sites $(P<0.05)$. Yeast, and to lesser extent bacteria, have been commonly associated with the fermentation of palm sap $[3,10,18]$. However, Karamoko et al. [12] report yeast/mould population of $3.2 \times 10^{3}, 2.3 \times 10^{7}, 1.2 \times 10^{8}, 1.6 \times 10^{8}$ and $1.0 \times$ $10^{8} \mathrm{cfu} / \mathrm{ml}$ for the first day, the first week, the second week, the third week, and the fourth week-old palm sap respectively.

The physicochemical properties of the fermented sap, of the first distillate, of the second distillate, of the first stillage, and of the second stillage are presented in Tables 2-6. The $\mathrm{pH}$ of the fermented palm sap 

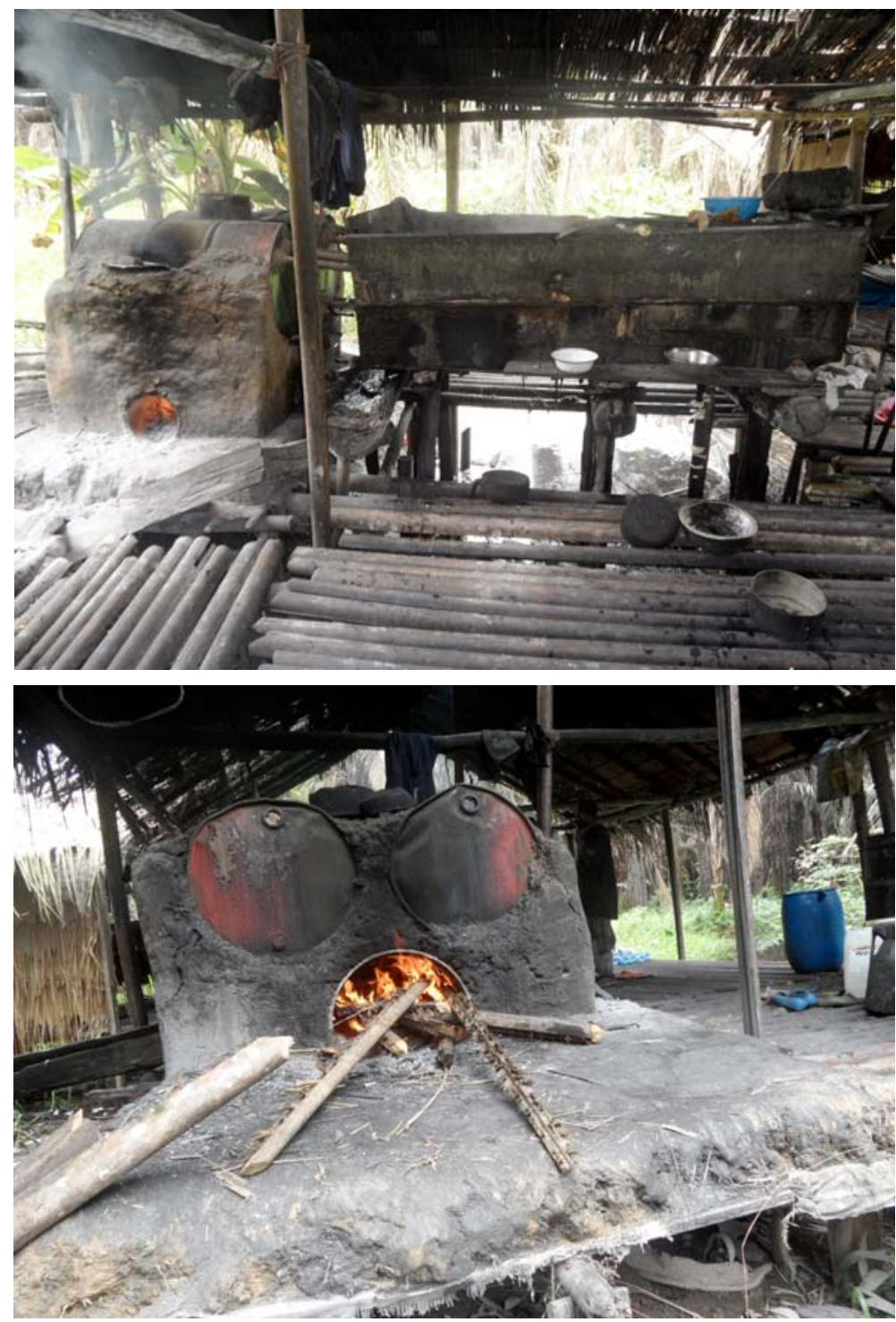

Figure 2: Rudimentary ethanol distillation equipment used in the Niger Delta.

Table 1: Volumes of Process Intermediates, Wood Energy Utilized, Duration and Manpower Input for the Traditional Fermentation and Distillation of Raffia Palm Sap to Ethanol

\begin{tabular}{|c|c|c|c|c|c|c|c|c|}
\hline & $\begin{array}{c}\text { Palm Wine Sap } \\
\text { volume, I }\end{array}$ & $\begin{array}{c}\mathbf{1}^{\text {st }} \text { distillate } \\
\text { volume, I }\end{array}$ & $\begin{array}{c}\mathbf{2}^{\text {nd }} \text { distillate } \\
\text { volume, I }\end{array}$ & $\begin{array}{c}\mathbf{1}^{\text {st }} \text { stillage } \\
\text { volume, I }\end{array}$ & $\begin{array}{c}\mathbf{2}^{\text {nd }} \text { stillage } \\
\text { volume, I }\end{array}$ & $\begin{array}{c}\text { Wood energy, } \\
\mathbf{k g}\end{array}$ & Duration & Employees \\
\hline \hline 1 & $280.000 \pm 0.289 \mathrm{a}$ & $43.700 \pm 0.115 \mathrm{a}$ & $20.000 \pm 0.577 \mathrm{a}$ & $236.300 \pm 0.173 \mathrm{a}$ & $23.700 \pm 0.115 \mathrm{a}$ & $117.630 \pm 0.012 \mathrm{~b}$ & $5 \mathrm{hr}: 32 \mathrm{Min}$. & 3 \\
\hline 2 & $480.000 \pm 2.887 \mathrm{e}$ & $79.080 \pm 0.012 \mathrm{~h}$ & $20.000 \pm 0.520 \mathrm{a}$ & $400.920 \pm 0.012 \mathrm{i}$ & $59.080 \pm 0.012 \mathrm{i}$ & $120.080 \pm 0.015 \mathrm{c}$ & $7 \mathrm{hrs}$ & 2 \\
\hline 3 & $480.000 \pm 5.774 \mathrm{e}$ & $71.733 \pm 0.007 \mathrm{~g}$ & $20.240 \pm 0.012 \mathrm{a}$ & $408.280 \pm 0.012 \mathrm{j}$ & $51.480 \pm 0.012 \mathrm{~h}$ & $124.217 \pm 0.132 \mathrm{e}$ & $9 \mathrm{hrs} 41 \mathrm{~min}$. & 5 \\
\hline 4 & $360.000 \pm 2.887 \mathrm{~d}$ & $56.163 \pm 1.318 \mathrm{ef}$ & $20.000 \pm 0.058 \mathrm{a}$ & $305.170 \pm 0.017 \mathrm{f}$ & $34.830 \pm 0.017 \mathrm{e}$ & $146.850 \pm 0.330 \mathrm{f}$ & $7 \mathrm{hrs}$ & 4 \\
\hline 5 & $360.000 \pm 2.309 \mathrm{~d}$ & $53.450 \pm 0.029 \mathrm{bc}$ & $20.000 \pm 0.115 \mathrm{a}$ & $306.550 \pm 0.012 \mathrm{~g}$ & $33.450 \pm 0.029 \mathrm{c}$ & $160.173 \pm 0.139 \mathrm{i}$ & $6 \mathrm{hrs} 47 \mathrm{~min}$. & 3 \\
\hline 6 & $320.870 \pm 0.012 \mathrm{c}$ & $54.817 \pm 0.007 \mathrm{~d}$ & $20.000 \pm 0.289 \mathrm{a}$ & $266.040 \pm 0.012 \mathrm{~d}$ & $34.830 \pm 0.015 \mathrm{e}$ & $104.597 \pm 0.101 \mathrm{a}$ & $\begin{array}{c}12 \mathrm{hrs} 33 \\
\mathrm{~min} .\end{array}$ \\
\hline 7 & $300.000 \pm 0.289 \mathrm{~b}$ & $56.550 \pm 0.029 \mathrm{f}$ & $20.000 \pm 0.265 \mathrm{a}$ & $243.450 \pm 0.029 \mathrm{~b}$ & $36.550 \pm 0.029 \mathrm{~g}$ & $153.080 \pm 0.072 \mathrm{~g}$ & $7 \mathrm{hrs} 54 \mathrm{~min}$. & 5 \\
\hline 8 & $360.000 \pm 2.887 \mathrm{~d}$ & $54.140 \pm 0.012 \mathrm{~cd}$ & $20.000 \pm 0.520 \mathrm{a}$ & $306.860 \pm 0.012 \mathrm{~h}$ & $34.140 \pm 0.012 \mathrm{~d}$ & $120.193 \pm 0.064 \mathrm{c}$ & $5 \mathrm{hrs} 56 \mathrm{~min}$. & 2 \\
\hline 9 & $300.000 \pm 0.289 \mathrm{~b}$ & $52.760 \pm 0.012 \mathrm{~b}$ & $20.000 \pm 0.115 \mathrm{a}$ & $247.240 \pm 0.012 \mathrm{c}$ & $32.760 \pm 0.012 \mathrm{~b}$ & $154.757 \pm 0.024 \mathrm{~h}$ & $7 \mathrm{hrs} 50$ \\
$\mathrm{minutes}$ & 3 \\
\hline 10 & $360.000 \pm 2.887 \mathrm{~d}$ & $55.170 \pm 0.017 \mathrm{de}$ & $20.000 \pm 0.404 \mathrm{a}$ & $304.830 \pm 0.017 \mathrm{e}$ & $35.170 \pm 0.012 \mathrm{f}$ & $121.397 \pm 0.095 \mathrm{~d}$ & $6 \mathrm{hrs} 30 \mathrm{~min}$. & 2 \\
\hline
\end{tabular}

Each value is expressed as mean \pm standard error $(n=3)$. Different letters in each column indicate significant differences at $P<0.05$ according to the Duncan Statistics. 
Table 2: Yeast Counts and Physicochemical Properties of Fermented Raffia Palm Sap

\begin{tabular}{|c|c|c|c|c|c|c|}
\hline & pH & $\begin{array}{c}\text { Electrical } \\
\text { Conductivity, } \mu \mathrm{S} / \mathrm{cm}\end{array}$ & Specific Gravity & $\%$ Alcohol & $\%$ Sugar & Yeast $\times 10^{8} \mathrm{cfu} / \mathrm{ml}$ \\
\hline 1 & $6.72 \pm 0.012 d$ & $21100 \pm 5.774 a$ & $1.006 \pm 0.001 \mathrm{c}$ & $12.00 \pm 0.058 c$ & $6.20 \pm 0.058$ ef & $6.667 \pm 0.001 b$ \\
\hline 2 & $6.59 \pm 0.006 a$ & $27100 \pm 5.774 \mathrm{~g}$ & $1.003 \pm 0.001 \mathrm{ab}$ & $13.00 \pm 0.100 \mathrm{e}$ & $12.60 \pm 0.058 h$ & $101.000 \pm 2.887 f$ \\
\hline 3 & $6.67 \pm 0.012 b c$ & $26150 \pm 5.774 f$ & $1.019 \pm 0.001 \mathrm{e}$ & $13.20 \pm 0.115 e$ & $4.60 \pm 0.100 d$ & $116.667 \pm 3.180 \mathrm{~g}$ \\
\hline 4 & $6.60 \pm 0.020 \mathrm{a}$ & $24050 \pm 0.000 d$ & $1.015 \pm 0.001 d$ & $15.30 \pm 0.058 \mathrm{~g}$ & $6.30 \pm 0.058 f$ & $185.637 \pm 0.052 i$ \\
\hline 5 & $6.65 \pm 0.010 b$ & $24500 \pm 10.000 \mathrm{e}$ & $1.007 \pm 0.001 c$ & $12.40 \pm 0.058 d$ & $3.00 \pm 0.100 \mathrm{a}$ & $65.330 \pm 0.068 d$ \\
\hline 6 & $6.77 \pm 0.010 \mathrm{e}$ & $30100 \pm 5.774 i$ & $1.001 \pm 0.001 \mathrm{a}$ & $11.50 \pm 0.100 b$ & $4.20 \pm 0.058 c$ & $1.653 \pm 0.001 \mathrm{ab}$ \\
\hline 7 & $6.70 \pm 0.010 \mathrm{~cd}$ & $23250 \pm 5.774 c$ & $1.005 \pm 0.001 b c$ & $12.40 \pm 0.058 d$ & $6.00 \pm 0.058 e$ & $49.333 \pm 0.007 c$ \\
\hline 8 & $6.70 \pm 0.012 \mathrm{~cd}$ & $21600 \pm 11.547 b$ & $1.002 \pm 0.000 a$ & $12.50 \pm 0.100 d$ & $3.40 \pm 0.100 \mathrm{~b}$ & $71.333 \pm 4.096 \mathrm{e}$ \\
\hline 9 & $6.76 \pm 0.010 \mathrm{e}$ & $28500 \pm 10.000 h$ & $1.007 \pm 0.001 c$ & $14.00 \pm 0.000 f$ & $7.20 \pm 0.058 \mathrm{~g}$ & $153.330 \pm 0.068 \mathrm{~h}$ \\
\hline 10 & $6.70 \pm 0.000 \mathrm{~cd}$ & $36750 \pm 5.774 j$ & $1.017 \pm 0.001 \mathrm{de}$ & $10.50 \pm 0.058 a$ & $3.60 \pm 0.058 b$ & $0.753 \pm 0.001 a$ \\
\hline
\end{tabular}

Each value is expressed as mean \pm standard error $(n=3)$. Different letters in each column indicate significant differences at $P<0.05$ according to the Duncan Statistics.

Table 3: Physicochemical Properties of First Distillate Produced During the Distillation of Raffia Palm Sap

\begin{tabular}{|c|c|c|c|c|c|}
\hline & $\mathbf{p H}$ & $\begin{array}{c}\text { Electrical } \\
\text { Conductivity, } \boldsymbol{\mu S} / \mathbf{c m}\end{array}$ & Specific Gravity & \% Alcohol & Sugar \\
\hline \hline 1 & $7.060 \pm 0.006 \mathrm{a}$ & $768.00 \pm 0.577 \mathrm{~d}$ & $0.968 \pm 0.001 \mathrm{c}$ & $18.833 \pm 0.441 \mathrm{a}$ & $3.567 \pm 0.120 \mathrm{c}$ \\
\hline 2 & $7.130 \pm 0.010 \mathrm{a}$ & $765.00 \pm 1.155 \mathrm{~d}$ & $0.976 \pm 0.001 \mathrm{e}$ & $20.000 \pm 0.000 \mathrm{ab}$ & $6.433 \pm 0.033 \mathrm{f}$ \\
\hline 3 & $7.250 \pm 0.010 \mathrm{ab}$ & $647.00 \pm 0.000 \mathrm{a}$ & $0.977 \pm 0.001 \mathrm{ef}$ & $20.167 \pm 0.333 \mathrm{~b}$ & $3.600 \pm 0.100 \mathrm{c}$ \\
\hline 4 & $7.437 \pm 0.012 \mathrm{ab}$ & $1898.33 \pm 1.202 \mathrm{i}$ & $0.974 \pm 0.001 \mathrm{de}$ & $39.000 \pm 0.577 \mathrm{~d}$ & $4.300 \pm 0.115 \mathrm{~d}$ \\
\hline 5 & $7.080 \pm 0.012 \mathrm{a}$ & $681.00 \pm 1.155 \mathrm{~b}$ & $0.963 \pm 0.001 \mathrm{~b}$ & $19.800 \pm 0.651 \mathrm{ab}$ & $2.200 \pm 0.100 \mathrm{a}$ \\
\hline 6 & $7.100 \pm 0.010 \mathrm{a}$ & $1823.00 \pm 1.528 \mathrm{~h}$ & $0.976 \pm 0.001 \mathrm{e}$ & $19.000 \pm 0.000 \mathrm{ab}$ & $3.400 \pm 0.000 \mathrm{c}$ \\
\hline 7 & $7.377 \pm 0.212 \mathrm{ab}$ & $793.00 \pm 1.528 \mathrm{e}$ & $0.979 \pm 0.000 \mathrm{f}$ & $19.500 \pm 0.289 \mathrm{ab}$ & $4.400 \pm 0.100 \mathrm{~d}$ \\
\hline 8 & $7.380 \pm 0.260 \mathrm{ab}$ & $1133.00 \pm 1.000 \mathrm{~g}$ & $0.778 \pm 0.001 \mathrm{a}$ & $20.000 \pm 0.289 \mathrm{ab}$ & $2.367 \pm 0.067 \mathrm{ab}$ \\
\hline 9 & $7.217 \pm 0.015 \mathrm{ab}$ & $1022.00 \pm 1.155 \mathrm{f}$ & $0.972 \pm 0.001 \mathrm{~d}$ & $23.000 \pm 0.289 \mathrm{c}$ & $5.100 \pm 0.058 \mathrm{e}$ \\
\hline 10 & $7.570 \pm 0.230 \mathrm{~b}$ & $745.00 \pm 0.577 \mathrm{c}$ & $0.974 \pm 0.002 \mathrm{de}$ & $19.000 \pm 0.289 \mathrm{ab}$ & $2.600 \pm 0.058 \mathrm{~b}$ \\
\hline
\end{tabular}

Each value is expressed as mean \pm standard error $(n=3)$. Different letters in each column indicate significant differences at $P<0.05$ according to the Duncan Statistics.

Table 4: Physicochemical Properties of Second Distillate Produced During the Distillation of Raffia Palm Sap

\begin{tabular}{|c|c|c|c|c|c|}
\hline & pH & Electrical Conductivity, $\mu \mathrm{S} / \mathrm{cm}$ & Specific Gravity & $\%$ Alcohol & $\%$ Sugar \\
\hline 1 & $6.650 \pm 0.015 f$ & $230.000 \pm 3.606 \mathrm{e}$ & $0.938 \pm 0.002 a b c$ & $50.667 \pm 0.441 b$ & $2.800 \pm 0.029 b$ \\
\hline 2 & $6.503 \pm 0.055 a b c$ & $219.000 \pm 1.000 d$ & $0.940 \pm 0.002 b c$ & $59.500 \pm 0.764 d$ & $3.500 \pm 0.100 f$ \\
\hline 3 & $6.630 \pm 0.006$ ef & $172.000 \pm 1.155 c$ & $0.959 \pm 0.012 d$ & $60.500 \pm 0.764 \mathrm{de}$ & $3.120 \pm 0.032 c$ \\
\hline 4 & $6.450 \pm 0.006 a$ & $100.000 \pm 1.732 a$ & $0.928 \pm 0.001 \mathrm{ab}$ & $61.500 \pm 0.289 e$ & $3.400 \pm 0.058$ ef \\
\hline 5 & $6.460 \pm 0.012 \mathrm{ab}$ & $217.000 \pm 1.528 d$ & $0.973 \pm 0.001 \mathrm{e}$ & $53.367 \pm 0.088 c$ & $1.900 \pm 0.050 a$ \\
\hline 6 & $6.550 \pm 0.012 \mathrm{~cd}$ & $105.333 \pm 2.333 a$ & $0.926 \pm 0.001 \mathrm{a}$ & $40.000 \pm 0.289 a$ & $3.100 \pm 0.029 c$ \\
\hline 7 & $6.570 \pm 0.010 \mathrm{de}$ & $280.000 \pm 2.887 f$ & $0.947 \pm 0.002 c$ & $53.000 \pm 0.289 c$ & $3.300 \pm 0.050 \mathrm{de}$ \\
\hline 8 & $6.490 \pm 0.015 a b c$ & $232.333 \pm 1.202 \mathrm{e}$ & $0.931 \pm 0.002 a b$ & $53.500 \pm 0.289 c$ & $2.000 \pm 0.029 a$ \\
\hline 9 & $6.520 \pm 0.010 \mathrm{bcd}$ & $130.000 \pm 1.528 b$ & $0.937 \pm 0.002 a b c$ & $61.000 \pm 0.289 e$ & $3.200 \pm 0.076 \mathrm{~cd}$ \\
\hline 10 & $6.450 \pm 0.010 a$ & $464.667 \pm 1.202 \mathrm{~g}$ & $0.962 \pm 0.001 \mathrm{de}$ & $39.000 \pm 0.289 a$ & $2.030 \pm 0.021 \mathrm{a}$ \\
\hline
\end{tabular}

Each value is expressed as mean \pm standard error $(n=3)$. Different letters in each column indicate significant differences at $P<0.05$ according to the Duncan Statistics. 
Table 5: Physicochemical Properties of First Stillage Produced During the Distillation of Raffia Palm Sap

\begin{tabular}{|c|c|c|c|c|c|}
\hline & pH & $\begin{array}{c}\text { Electrical } \\
\text { Conductivity, } \boldsymbol{\mu S} / \mathbf{c m}\end{array}$ & Specific Gravity & \% Alcohol Sugar & \% \\
\hline \hline 1 & $7.200 \pm 0.029 \mathrm{~b}$ & $12400 \pm 7.638 \mathrm{~b}$ & $0.999 \pm 0.002 \mathrm{a}$ & $10.200 \pm 0.058 \mathrm{~g}$ & $0.800 \pm 0.058 \mathrm{bc}$ \\
\hline 2 & $7.107 \pm 0.015 \mathrm{a}$ & $16900 \pm 2.887 \mathrm{f}$ & $1.008 \pm 0.001 \mathrm{c}$ & $8.000 \pm 0.058 \mathrm{~d}$ & $1.200 \pm 0.058 \mathrm{~d}$ \\
\hline 3 & $7.160 \pm 0.006 \mathrm{ab}$ & $16350 \pm 5.000 \mathrm{e}$ & $1.002 \pm 0.001 \mathrm{ab}$ & $6.467 \pm 0.067 \mathrm{c}$ & $1.000 \pm 0.058 \mathrm{c}$ \\
\hline 4 & $7.200 \pm 0.010 \mathrm{~b}$ & $13700 \pm 2.887 \mathrm{c}$ & $1.007 \pm 0.001 \mathrm{c}$ & $5.800 \pm 0.058 \mathrm{a}$ & $1.500 \pm 0.058 \mathrm{e}$ \\
\hline 5 & $7.180 \pm 0.006 \mathrm{~b}$ & $11150 \pm 2.887 \mathrm{a}$ & $1.005 \pm 0.001 \mathrm{bc}$ & $6.200 \pm 0.058 \mathrm{~b}$ & $0.800 \pm 0.000 \mathrm{bc}$ \\
\hline 6 & $7.200 \pm 0.010 \mathrm{~b}$ & $17710 \pm 2.887 \mathrm{i}$ & $1.000 \pm 0.003 \mathrm{a}$ & $9.400 \pm 0.058 \mathrm{e}$ & $0.500 \pm 0.058 \mathrm{a}$ \\
\hline 7 & $7.260 \pm 0.010 \mathrm{c}$ & $29500 \pm 5.774 \mathrm{j}$ & $0.999 \pm 0.001 \mathrm{a}$ & $9.600 \pm 0.000 \mathrm{f}$ & $0.700 \pm 0.100 \mathrm{ab}$ \\
\hline 8 & $7.270 \pm 0.015 \mathrm{c}$ & $17350 \pm 2.887 \mathrm{~h}$ & $0.999 \pm 0.001 \mathrm{a}$ & $9.400 \pm 0.058 \mathrm{e}$ & $0.600 \pm 0.100 \mathrm{ab}$ \\
\hline 9 & $7.290 \pm 0.017 \mathrm{c}$ & $15350 \pm 7.638 \mathrm{~d}$ & $1.000 \pm 0.002 \mathrm{a}$ & $9.500 \pm 0.100 \mathrm{ef}$ & $0.500 \pm 0.058 \mathrm{a}$ \\
\hline 10 & $7.270 \pm 0.012 \mathrm{c}$ & $16960 \pm 25.166 \mathrm{~g}$ & $1.001 \pm 0.001 \mathrm{ab}$ & $6.600 \pm 0.058 \mathrm{c}$ & $0.800 \pm 0.058 \mathrm{bc}$ \\
\hline
\end{tabular}

Each value is expressed as mean \pm standard error $(\mathrm{n}=3)$. Different letters in each column indicate significant differences at $P<0.05$ according to the Duncan Statistics.

Table 6: Physicochemical Properties of Second Stillage Produced During the Distillation of Raffia Palm Sap

\begin{tabular}{|c|c|c|c|c|c|}
\hline & $\mathbf{p H}$ & $\begin{array}{c}\text { Electrical } \\
\text { Conductivity, } \boldsymbol{\mu S} / \mathbf{c m}\end{array}$ & Specific Gravity & \% Alcohol & \% Sugar \\
\hline \hline 1 & $6.440 \pm 0.015 \mathrm{f}$ & $12105 \pm 2.887 \mathrm{~b}$ & $1.001 \pm 0.001 \mathrm{a}$ & $5.800 \pm 0.058 \mathrm{f}$ & $0.300 \pm 0.058 \mathrm{bc}$ \\
\hline 2 & $6.340 \pm 0.006 \mathrm{~cd}$ & $19805 \pm 2.887 \mathrm{i}$ & $1.001 \pm 0.001 \mathrm{a}$ & $4.200 \pm 0.058 \mathrm{~cd}$ & $0.200 \pm 0.000 \mathrm{ab}$ \\
\hline 3 & $6.360 \pm 0.006 \mathrm{~d}$ & $16700 \pm 30.503 \mathrm{f}$ & $1.007 \pm 0.001 \mathrm{~b}$ & $4.000 \pm 0.000 \mathrm{bc}$ & $0.300 \pm 0.058 \mathrm{bc}$ \\
\hline 4 & $6.290 \pm 0.010 \mathrm{~b}$ & $18430 \pm 2.887 \mathrm{~h}$ & $1.001 \pm 0.001 \mathrm{a}$ & $4.100 \pm 0.058 \mathrm{~cd}$ & $0.300 \pm 0.058 \mathrm{bc}$ \\
\hline 5 & $6.320 \pm 0.010 \mathrm{c}$ & $18030 \pm 2.887 \mathrm{~g}$ & $1.001 \pm 0.001 \mathrm{a}$ & $4.300 \pm 0.058 \mathrm{~d}$ & $0.200 \pm 0.058 \mathrm{ab}$ \\
\hline 6 & $6.430 \pm 0.006 \mathrm{f}$ & $11360 \pm 2.887 \mathrm{a}$ & $1.003 \pm 0.001 \mathrm{a}$ & $5.200 \pm 0.058 \mathrm{e}$ & $0.100 \pm 0.000 \mathrm{a}$ \\
\hline 7 & $6.360 \pm 0.010 \mathrm{~d}$ & $15333 \pm 30.867 \mathrm{~d}$ & $1.001 \pm 0.001 \mathrm{a}$ & $4.100 \pm 0.058 \mathrm{~cd}$ & $0.300 \pm 0.058 \mathrm{bc}$ \\
\hline 8 & $6.390 \pm 0.006 \mathrm{e}$ & $13650 \pm 5.774 \mathrm{c}$ & $1.003 \pm 0.001 \mathrm{a}$ & $3.400 \pm 0.000 \mathrm{a}$ & $0.400 \pm 0.058 \mathrm{c}$ \\
\hline 9 & $6.200 \pm 0.010 \mathrm{a}$ & $15600 \pm 7.638 \mathrm{~d}$ & $1.001 \pm 0.001 \mathrm{a}$ & $3.800 \pm 0.153 \mathrm{~b}$ & $0.200 \pm 0.058 \mathrm{ab}$ \\
\hline 10 & $6.537 \pm 0.012 \mathrm{~g}$ & $16250 \pm 2.887 \mathrm{e}$ & $1.001 \pm 0.000 \mathrm{a}$ & $5.400 \pm 0.058 \mathrm{e}$ & $0.400 \pm 0.058 \mathrm{c}$ \\
\hline
\end{tabular}

Each value is expressed as mean \pm standard error $(\mathrm{n}=3)$. Different letters in each column indicate significant differences at $P<0.05$ according to the Duncan Statistics.

(6.59-6.77), of the second distillate (6.45-6.65), and of the second stillage (6.20-6.54) were slightly acidic, while that of the first distillate (7.10-7.57) and of the first stillage (7.11-7.29) were neutral. Stillage from molasses and sugarcane juice have been reported to have a $\mathrm{pH}$ of 4.8 and 3.7-5.9 respectively [2]. Adeleke and Abiodun [21] report a $\mathrm{pH}$ of 4.3 and 6.3 for palm sap and ethanol respectively. Nwanchukwu et al. [14] revealed that the $\mathrm{pH}$ of palm sap decreases with age i.e. the length of fermentation. Several authors have reported a concurrent alcoholic, acetic and lactic acid fermentation of palm sap, which is responsible for the rapid acidification of the palm sap [10, 12, 13, 17, 39].

The specific gravity was significantly different in the studied sites and among the various intermediates
$(P<0.05)$. The specific gravity of the fermented sap, of the first and second stillage were slightly greater than 1 , while that of the first and second distillates were slightly lesser than 1. Adeleke and Abiodun [21] report specific gravity of 0.9897 for ethanol and 1.0387 for fermented palm sap. Willington and Marten [2] report a specific gravity of 1.05 for molasses. The electrical conductivity was highest in the palm sap $(21,100$ $36,750 \mu \mathrm{S} / \mathrm{cm})$, of the first stillage $(11,150-29,500$ $\mu \mathrm{S} / \mathrm{cm})$ and of the second stillage $(11,360-19,805$ $\mu \mathrm{S} / \mathrm{cm})$, and least in the first distillate (647-1898 $\mu \mathrm{S} / \mathrm{cm})$ and second distillate $(100-464 \mu \mathrm{S} / \mathrm{cm})$.

The total sugar percentage was highest in the fermented sap (3.00-12.60\%), followed by the first distillate $(2.20-6.43 \%)$, the second distillate (1.90- 
$3.50 \%)$ and least in the first stillage (0.50-1.50\%) and second stillage $(0.10-0.40 \%)$, though significantly different in the various sites $(P<0.05)$. Several authors have reported the total sugar of unfermented palm sap to be in the order of $10-12 \%[3,12,40]$. Rokosu and Nwisienyi [17] report $4-7 \%$ total sugar in unfermented palm sap. Being a substrate for the production of ethanol, expectedly the palm sap had the highest sugar level, which declined afterwards.

The percentage of ethanol was significantly different $(P<0.05)$ among the different intermediates. The highest ethanol percentage was recorded in the second distillate $(39-61.5 \%)$, followed by the first distillate $(18.83-39 \%)$, the first stillage $(5.80-10.20 \%)$, the palm sap (10.50-15.30\%), and the second stillage (3.40$5.80 \%$ ). Several authors have reported various levels of ethanol in fermented palm sap, including 2-8\% [27], $3.25 \%$ [17], 3.1\% [21], 0.5-7.1\% [13], 8.2\% [6, 14], 3$4 \%$ [20]. Similarly, several authors have reported the ethanol level produced from sap distillation to be $>40 \%$ [20], 26.8-39.9\% [13], 37.6\% [21], 40\% [27].

On the positive side, the production of ethanol fuel from raffia palm would allow the indigenous people to participate in the energy sector, which has long been dominated by multinationals. Indigenous people could participate in the entire value chain of fuel ethanol production, including palm wine tapping, transportation, fermentation, distillation and distribution, unlike multinational biofuel companies that engage indigenous people only in farm-related activities. However, there are several challenges associated with the traditional fermentation and distillation of palm sap for ethanol production that must be addressed in order to scale up the process. Some of the limiting factors include microbial contamination, poor distillation apparatus, inefficient energy utilization, and lack of ethanol dehydration technology and the production of large volume of stillage.

For the traditional fermentation and distillation of raffia palm to be used for the production of fuel ethanol, the process must first be upgraded. For instance, inoculation of fresh palm sap is spontaneous i.e. left to chance inoculation, which is prone to contamination by other microbes, producing competing products such as lactic and acetic acid [10,12, 13, 17, 39]. In order to prevent or reduce microbial contamination, it is suggested that the ethanol fermenting yeast be isolated, developed, and used under sterile conditions. Yeast strain with high ethanol yield and tolerance was recorded in this study, which agreed with other findings in literature $[12,14]$.
The ethanol produced by the smallholders is of low concentration, typically in the range of $39-61.5 \%$ ethanol. The smallholders lacked the technology for ethanol dehydration such as the use of molecular sieves, azeotropic distillation, counter current distillation etc. This challenge can be overcome by modifying the Nigerian Biofuel Policy [41] to permit the use of low concentration ethanol cooking fuel [42] as practiced in India [43-45] and hydrous ethanol for automobiles, as commonly practiced in Brazil [31, 32].

Another problem faced by the smallholder distillers is the poor energy efficiency of rudimentary distillation apparatus (Figure 2) used for distillation, which has resulted in large energy input. The Nigerian government, through its research institutions like the Nigeria Institute for Oil Palm Research (NIFOR), the Federal Institute of Industrial Research (FIIRO), the National Centre for Agricultural Mechanization (NCAM), and the Project Development Agency (PRODA),are encouraged to modernize the distillers and equip them with process-control features. Meanwhile, it has been reported that raffia palm is hapazanthic i.e. the palm would die after fruiting once $[7,8]$, thus resulting in the loss of biomass and the release of carbon into the environment. It is therefore recommended that raffia palm wood and fronds be used as energy source for distillation, which could offset the potentially negative energy balance associated with the poor distillation process. The practice of using raffia stems, trunk and fronds from tapped trees is currently being practiced by some smallholders. These lignocellulosic biomass can be converted to ethanol by dilute-acid pretreatment, enzymatic saccharification, and co-fermentation [46]. Also, excess raffia palm stem and fronds can be used as fuel for power generation via steam cycle or for advanced fuel and power generation via gasification and the Fischer-Tropsch synthesis. The ripe fruit can be harvested, oil extracted and used for biodiesel production. The seeds can be used for the propagation of raffia palm or as fuel for steam boilers for electricity generation. All these innovations could increase the energy efficiency of biofuel production from raffia palm.

Stillage and yeast are by-products from any ethanol production facility. In Nigeria, the smallholder ethanol distillers typically dispose these by-products into the environment, which potentially pollute the ecosystem [26]. The sustainability of the smallholder ethanol process is largely dependent on the distillation and recycling of these waste by-products [22]. Ethanol fermenting yeasts have been successfully used as animal feeds. From this study, primary stillage has a 
considerable level of ethanol (5.8-10.2\%) and sugars (0.5-1.5\%), while the secondary stillage has lesser levels of alcohol (3.4-5.8\%) and sugar (0.2-0.4\%). Hence, these by-products could be recycled to recover more ethanol. They could also be used as fertiirrigation. The use of ethanol fermentation by-products for animal feed and ferti-irrigation could further increase the energy efficiency and sustainability of the process. Finally, the use state-of-the-art technology such as dilute-acid pretreatment, enzymatic saccharification, and fermentation, optimization of product recovery, and wastewater utilization could significantly improve the traditional ethanol production process [46]. However, these high technologies may be unavailable to the rural processors in the near future.

\section{CONCLUSION}

This research was designed to present the process of traditional fermentation and distillation of beverage ethanol in Bayelsa State, Nigeria, and to investigate the possibility of scaling up the process for the production of fuel ethanol. Ten smallholder ethanol production facilities were randomly selected and triplicate samples of the process intermediates were collected and analysed including fermented palm sap, first and second distillate, first and second stillage. Results show that the ethanol percentage was significantly different $(P<0.05)$ among the different intermediates. The highest ethanol was recorded in the second distillate (39-61.5\%), followed by the first distillate (18.83-39\%), first stillage $(5.80-10.20 \%)$, palm sap (10.50-15.30\%) and second stillage (3.40-5.80\%).

The smallholder ethanol production facilities are challenged by;

- the entire process is not done under aseptic conditions but is dependent on spontaneous (i.e. chance) inoculation, which is prone to contamination by competing microorganisms catalyzing the production of other products such as lactic and acetic acid,

- the use of makeshift distillation apparatus, which is energy inefficient and lacked process control,

- $\quad$ production of large volume of stillage, which is typically disposed into the environment, without any form of treatment,

- $\quad$ production of low concentration ethanol (39$61.5 \%$ ) that cannot be blended with gasoline to comply with Nigeria's E10 gasoline/ethanol blend policy.

These challenges could be overcome by modernization of the distillation apparatus, and upgrading of the Nigerian Biofuel Policy to permit the use of hydrous ethanol in automobiles and low concentration ethanol for domestic/household cooking. The study concludes that it is feasible to scale up the traditional process for fuel ethanol production, which has the added benefit of engaging indigenous people in the entire value chain of fuel ethanol production.

\section{ACKNOWLEDGEMENT}

This study was based on the undergraduate project work of Patrick Tuwon and Ekiemene Ayibaebi supervised by Dr. Elijah Ohimain at the Niger Delta University. The authors wish to thank Mr. Suoye Spiff of the Central Analytical Laboratory and Mr. Okon Ukpe of the Microbiology Laboratory for the physico-chemical and yeast population analyses respectively.

\section{REFERENCES}

[1] Pant D, Adholeya A. Biological approaches for treatment of distillery wastewater: A review. Biores Technol 2007; 98: 23321-34. http://dx.doi.org/10.1016/i.biortech.2006.09.027

[2] Willington IP, Marten GG. Options for handling stillage waste from sugar-based fuel ethanol production. Res Cons1982; 8: 111-129.

http://dx.doi.org/10.1016/0166-3097(82)90036-0

[3] Ogbulie TE, Ogbulie JN, Njoku HO. Comparative study on the microbiology and shelf life stability of palm wine from Elaeis guineensis and Raphia hookeri obtained from Okigwe, Nigeria. Afri J Biotechnol 2007; 6(7): 914-22.

[4] Bechem EET, Omoloko C, Nwaga D, Titanji VPK. Characterization of palm wine yeast using osmotic ethanol tolerance and isozyme polymorphism of alcohol dehydrogenase. Afri J Biotechnol 2007; 6(14): 1715-19.

[5] Iwuoha $\mathrm{Cl}$, Eke OS. Nigerian indigenous fermented foods: their traditional process operation, inherent problems, improvement and current status. Food Res Int 1996; 29(5-6): 527-40. http://dx.doi.org/10.1016/0963-9969(95)00045-3

[6] Nwachukwu IN, Ibekwe VI, Anyanwu BN. Investigation of some physic-chemistry and microbial succession parameters of palm wine. J Food Technol 2006a; 4(4): 308-12.

[7] Obahiagbon FI. A review of the origin, morphology, cultivation, economic products, health and physiological implications of raphia palm. Afri J Food Sci 2009; 3(13): 44753.

[8] Obahiagbon FI, Osagie AU. Sugar and macrominerals composition of sap produced by Raphia hookeri palms. Afri J Biotechnol 2007; 6(6): 744-50.

[9] Eze OM, Ogan U. Sugar and unfermented sap and the wine from the oil palm, Elaeis guineensis tree. Hum Nutr 1988; 38: 121-26.

http://dx.doi.org/10.1007/BF01091716 
[10] Kosugi A, Tanaka R, Magara K, Murata $\mathrm{Y}$, Arai $\mathrm{T}$, et al. Ethanol and lactic acid production using sap squeezed from old oil palm trunks felled for replanting. J Biosci Bioeng 2010; 110 (3): 322-25.

http://dx.doi.org/10.1016/j.jbiosc.2010.03.001

[11] Obire O. Activity of Zymomonas species in palm sap obtained from three areas in Edo state, Nigeria. J Appl Sci Environ Manage 2005; 9: 25-30.

[12] Karamoko D, Djeni NT, N'guessan KF, Bouatenin KMJ, Dje $\mathrm{KM}$. The biochemical and microbiological quality of palm wine samples produced at different periods during tapping and changes which occurred during their storage. Food control 2012; 26; 504-11.

http://dx.doi.org/10.1016/j.foodcont.2012.02.018

[13] Igbibadolor RO. Other Tropical Fruit Vinegars. In Solieri L, Giudici P, Eds. Vinegars of the World. Springer Verlag, Italia 2009; pp. 262-71.

[14] Nwachukwu IN, lbekwe VI, Nwabueze RN, Anyanwu BN. Characterization of palm wine yeast isolates for industrial utilization. Afri J Biotechnol 2006; 5 (19): 1725-1728

[15] Awudza JA, Kufuor FA. Production of ethanol from cassava and sweet potatoes using yeast extracts from palm wine. $J$ Univ Sci Technol Kumasi 1991; 11(1): 20-26.

[16] Ezeronye OU, Okerentugba PO. Genetic and physiological variants of yeast selected from palm wine. Mycopathologia 2000; 152: 85-89.

http://dx.doi.org/10.1023/A:1012323721012

[17] Rokosu AA, Nwisienyi JJ. Variation in the composition of palm wine during fermentation. Enzyme Microbe Technol 1980; 2: 63-65.

http://dx.doi.org/10.1016/0141-0229(80)90011-3

[18] Stringini M, Comitini F, Taccari M, Ciani M. Yeast diversity during tapping and fermentation of palm wine from Cameroon. Food Microbial 2009; 26: 415-20.

[19] Blume D. Alcohol can be a Gas: fuelling the ethanol revolution for the $21^{\text {st }}$ century. The International Institute for Ecological Agriculture, Santa Cruz, California 2007.

[20] Obot IS. The measurement of drinking patterns and alcohol problems in Nigeria. J Subst Abuse 2000; 12: 169-81. http://dx.doi.org/10.1016/S0899-3289(00)00047-X

[21] Adeleke RO, Abiodun OA. Physicochemical properties of commercial local beverages in Osun State, Nigeria. Pakis J Nutri 2010; 9(9): 853-55. http://dx.doi.org/10.3923/pjn.2010.853.855

[22] Wilkie AC, Riedesel KJ, Owens JM. Stillage characterization and anaerobic treatment of ethanol stillage from conventional and cellulosic feedstocks. Biomass Bioenergy 2000; 19; 63102.

http://dx.doi.org/10.1016/S0961-9534(00)00017-9

[23] Barnes CC, Halbert EJ. Alcohol manufacture -wastewater treatment. Water 1979; 6: 20-23.

[24] Beltran FJ, Alvarez PM, Rodriguez, EM, Gracia-Araya JF, Rivas J. Treatment of high strength distillery wastewater (cherry stillage) by integrated aerobic biological oxidation and ozonation. Biotechnol Prog 2001; 17: 462-67.

http://dx.doi.org/10.1021/bp010021c

[25] Van Haandel AC, Catunda PFC. Profitability increase of alcohol distilleries by the rational use of byproducts. Water Sci Technol 1994; 29(8): 117-24.

[26] Nandy T, Shastry S, Kaul SN. Wastewater management in a cane molasses distillery involving bioresource recovery. $\mathrm{J}$ Environ Manag 2002; 65: 25-38.

http://dx.doi.org/10.1006/jema.2001.0505

[27] Oladeinde FO, Nwankwo El, Moronkola OA, Amosu MA, Farayola B. Determination of indigenous and foreign alcohol beverages levels in urine by quantitative inferred spectroscopy. Afri J Biomed Res 2002; 5: 73-76.
[28] Ababio OY. Organic chemistry in new school chemistry, Africa-fep publishers limited $1^{\text {st }}$ ed., 1990.

[29] Ohimain El. Environmental impacts of smallholder ethanol production from cassava feedstock for the replacement of kerosene household cooking fuel in Nigeria. Energy Sources Part A 2012a; In press.

[30] Pimentel D. Ethanol fuels: energy balance, economics, and environmental impacts are negative. Natur Resour Res 2003; 12(2): 127-34.

http://dx.doi.org/10.1023/A:1024214812527

[31] Zanin GM, Santata CC, Bon PS, Giordano RCL, De Moraes $\mathrm{FF}$, et al. Brazilian bioethanol program. Appl Biochem Biotechnol 2000; 84-86: 1147-61. http://dx.doi.org/10.1385/ABAB:84-86:1-9:1147

[32] Geller SH. Ethanol fuel from sugar cane in Brazil. Ann Rev Energy 1985; 10: 135-64. http://dx.doi.org/10.1146/annurev.eg.10.110185.001031

[33] Ohimain El. Emerging bio-ethanol projects in Nigeria; their opportunities and challenges. Energy Policy 2010; 38: 716168.

\section{http://dx.doi.org/10.1016/j.enpol.2010.07.038}

[34] Tangka JK, Berinyuy JE, Tekounegnin N, Okale AN Physicochemical properties of bio-ethanol/gasoline blends and the qualitative effect of different blends on gasoline quality and engine performance. J Petrol Technol Alternat Fuels $2011 ; 2(3)$ : 35-44.

[35] Lynd LR, Cushman JH, Nichols RJ, Wyman CE. Fuel ethanol from cellulosic biomass. Science 1991; 251: 1318-23. http://dx.doi.org/10.1126/science.251.4999.1318

[36] Malik US, Ahmed M, Sombilla MA, Cueno SL. Biofue production for smallholder producers in the Greater Mekong Sub-region. Appl Energy 2009; 86: S58-S68. http://dx.doi.org/10.1016/j.apenergy.2009.04.048

[37] Fuwape JA, Akindele SO. Biomass yield and energy value of some fast-growing multipurpose trees in Nigeria. Biomass Bioenergy 1997; 12(1): 101-106. http://dx.doi.org/10.1016/S0961-9534(96)00061-X

[38] Nwanchukwu CC, Lewis C. A net energy analysis of fuels from biomass: the case of Nigeria. Biomass 1986; 11: 27189.

http://dx.doi.org/10.1016/0144-4565(86)90099-5

[39] Amoa-Awuaa WK, Sampson E, Tano-Debrah K. Growth of yeasts, lactic and acetic acid bacteria in palm wine during tapping and fermentation from felled oil palm in Ghana. Appl Microbiol 2007; 38: 1-7.

[40] Okafor N. Preliminary microbiological studies on the preservation of palm wine. J Appl Bacteriol 1975; 102: 599606.

[41] NNPC. Draft Nigerian Bio-fuel policy and incentives. Nigerian National Petroleum Corporation (NNPC), Abuja, Nigeria. 2007.

[42] Ohimain El. The benefits and potential impacts of household cooking fuel substitution with bio-ethanol produced from cassava feedstock in Nigeria. Energy Sust Dev 2012b; 16: 352-62.

http://dx.doi.org/10.1016/j.esd.2012.06.003

[43] Rajvanshi AK. Ethanol fuel for rural households.Nimbkar Agricultural Research Institute, Maharashtra, India. 2006 http://nariphaltan.virtualave.net/ruralethanol.pdf. Accessed 12 December 2009.

[44] Rajvanshi AK, Patil SM, Mendonca B. Low concentration ethanol stove for rural areas in India. Energy Sust Dev 2007; 11(1): 63-67.

[45] Robinson J. Bio-ethanol as a household cooking fuel. A mini pilot study of the superblu stove in peri-urban Malawi. MSc Thesis, Loughborough University, Leics, UK 2006. 
[46] Humbird D, Davis R, Tao L, Kinchin C, Hsu D, Aden A, et al. Process Design and Economics for Biochemical Conversion of Lignocellulosic Biomass to Ethanol: Dilute-Acid Pretreatment and Enzymatic Hydrolysis of Corn Stover.
National Renewable Energy Laboratory report. 2011; p. 147. NREL Report No. TP-5100-47764. 